\section{EDUCATION}

Research, Innovation and Solutions on-line ${ }^{(2)}$
PSYCHOLOGY

I+D+i

\section{Electronic Journal of Research}

in Educational Psychology

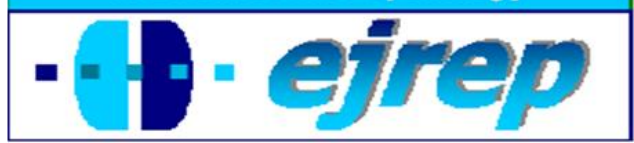

\title{
The Effects of Reading Racetrack with Direct Instruction Flashcards and a Token System on Sight Word Acquisition For Two Primary Students with Severe Conduct Disorders
}

Kim Hopewell ${ }^{1}$, T. F. McLaughlin ${ }^{2}$, K. Mark Derby ${ }^{3}$, etc.

1,2 and 3 Department Department of Special Education, Gonzaga University, USA

USA

Correspondence: T. F. McLaughlin, Department of Special Education, Gonzaga University, East 501 Boone Avenue, AD Box 25, Spokane, WA, USA 99258-0025; e-mail: mclaughlin@gonzaga.edu

(C) Education \& Psychology I+D+i and Editorial EOS (Spain) 


\begin{abstract}
Introduction. The purpose of the study was to evaluate the effectiveness of reading racetracks and direct instruction flashcards with two students with behavior disorders. A token economy with a response cost component was also implemented to increase on-task behavior during data collection.
\end{abstract}

Method. The participants were two eight-year-old males. Both were labeled as having severe behavior disorders. A multiple baseline design was used across the two students to evaluate the effects of the intervention package. Corrects and errors were recorded and tracked over selected word lists employed in the school district.

Results. Both students showed an increase in correct responses and a decrease in errors when the intervention package was in effect. According to the classroom staff, both students became more confident in their reading.

Discussion and Conclusion The practicality of employing these procedures is also outlined. The paper provides an additional replication of employing DI flashcards and Reading racetracks to a different set of students.

Key words: elementary students with behavior disorders, reading racetracks, classroom research, token reinforcement program, self-contained classroom setting, sight words 


\section{Los efectos del "Reading Racetrack" en el reconocimiento de palabras en dos alumnos de Educación Primaria con graves trastornos de conducta Resumen}

Introducción. El propósito del estudio fue evaluar la eficacia de las pistas durante la lectura y de los tarjetas (flashcards) de instrucción directa, con dos estudiantes con desordenes del comportamiento. Para aumentar comportamiento de recogida de datos durante la tarea, fue implementada una economía simbólica con un componente de coste de la respuesta.

Método. Los participantes fueron dos varones de ocho años. Durante la recogida de datos del comportamiento durante la tarea, participaron dos varones de ocho años, con un diseño de línea base múltiple. Las correciones y los errores fueron registrados y seguidos sobre listas de palabras seleccionadas y empleadas en el distrito escolar.

Resultados. Ambos estudiantes mostraron un aumento en respuestas correctas y una disminución de errores cuando se analizó el conjunto de la intervención.

Discusión y Conclusión. Cuando se analiza el conjunto de la intervención los efectos son significativos. Se resumen y analiza el sentido práctico de emplear estos procedimientos.

Palabras Clave: estudiantes elementales con los desordenes del comportamiento, leyendo pistas, investigación de la sala de programa simbólico del refuerzo, configuración autónoma de la sala de clase, palabras de la vista 


\section{Introduction}

Reading is a key to successful life. Reading is needed to succeed in the classroom, to enter the career world, and also to be functional in society (Adams, 1990; Liberman \& Liberman 1990). Unfortunately, reading is a skill that is lacking for many school children across the country (National Reading Panel, 1999; National Research Council, 1998). Teaching reading begins at a young age and if any of the basic components are left out, the student may be unable to decode or comprehend the text Cunningham \& Stanovich, 1997). The first few years of a child's life in school are essential for teaching reading (National Reading Panel 1999). Educators continue to disagree how to teach reading, whole language verse direct instruction, but over all the noise of the debate, one sound rings clear - reading needs to be taught (Krashen, 2002; Reyhner, 2008). Reading can be a challenge to teach, however, when done effectively it can truly impact a student's school and social life.

The number of students being diagnosed with behavior disorders continues to increase (Trout, Epstein, Nelson, Synhorst, \& Hurley, 2006). Students with a behavior disorder have an underlying behavior issue that often interferes the learning in the classroom (Heward, 2008). Another common characteristic of students with behavior disorders is below grade level achievement (Morgan \& Jenson, 1988). Students who have a behavior disorder are at risk for a reading deficiency. Studies have shown students with an emotional or behavior disorder tend to be one to two years below grade level for reading (Barton-Arwood, Wehby, \& Falk, 2005). Academically students with behavior disorders do not have promising outcomes (Trout et al., 2006). With an emphasis in many classrooms on remediating their inappropriate social behaviors, academics may well fall to the wayside (Barton-Arwood et al., 2005). It is important to focus on reading and providing early intervention for those skills. Success in reading can help the student find success in other aspects of his or her schooling (Carnine, Silbert, Kameenui, \& Tarver, 2010).

Employing evidence-based practices for both academic and social skills can be a key for finding success for students. Research shows that direct instruction can be the most successful way to instruct students (Marchand-Martella, Slocum, \& Martella, 2004). Project Follow Through contains the largest body of research that shows direct instruction reading was superior to learning centers, open education, and self-directed literature (Gettinger, 1985; Grossen, 1995). A drill and practice procedure from direct instruction called Direct Instruc- 
tion (DI) flashcards has been very successful in teaching students basic skills (Brasch, Williams, \& McLaughlin, 2008; Hayter, Weber, McLaughlin, \& Scott, 2007; Kaufman, McLaughlin, Derby, \& Waco, 2011; Ruwe, McLaughlin, Derby, \& Johnson, 2011; Silbert, Carnine, \& Stein, 1981). Direct Instruction flashcards is a method of presenting flashcards with immediate feedback. The flashcards are presented, several seconds are given for the student to respond, and then feedback is given. The feedback is telling the student that he or she responded correctly, telling the student the correct response, or giving an error correction. If a flashcard is missed then it is placed back in the stack being presented. The DI flashcards have also shown through research to be very successful in teaching students a variety of information from sight words to math multiplication tables (Brasch et al., 2008; Green, McLaughlin, Derby, \& Lee, 2010; Sante, McLaughlin, \&Weber 2001).

Research has also indicated that reading racetracks (RR) can also be effective in teaching students to read sight words (Alexander, McLaughlin, Derby, \& Cartmell, 2008; Falk, Band, \& McLaughlin, 2003; McLaughlin, Weber, Derby, Hyde, Violette, Barton, et al. 2009; Rinaldi \& McLaughlin, 1996; Rinaldi, Sells, \& McLaughlin, 1997). Reading racetracks are a form of instruction using a track with twenty-eight cells to discrete information such as sight words. The track looks like a racecar track with a start and finish. There are two pictures of cars on the track. In the reading racetrack, words are placed in each cell. The students read around the track in one minute. Fluency and accuracy are increased with the reading racetrack. Reading racetracks allow for a large number of sight words or other discrete academic skills to be taught to the students in a systematic and fun way.

\section{Objetives}

This study was implemented examine the use of direct instruction flashcards, reading racetracks, and a token economy with primary students enrolled in a self-contained behavior intervention classroom. Since most of the previous research with reading racetracks involved students with mild disabilities, a second purpose was to expand the efficacy of reading racetracks and DI flashcards for students with severe behavior disorders. Increasing the students' literacy knowledge should allow them to be more quickly integrated into general education classroom settings. 


\section{Method}

\section{Participants and Settings}

There were two participants in this study. Participant 1 was a seven-year-old male who turned eight during the course of the study. He was placed in the behavior intervention classroom due to the behaviors he displayed when he was removed from the home by Child Protective Services (CPS) at age five. Later he was diagnosed with a conduct disorder (CD). He had major difficulties in reading, writing and mathematics, but reading was his largest deficit area. He was chosen for the study because he was a quick learner and enjoyed learning something new. Reading was also an area that was affecting all other subject areas for this participant and by increasing his knowledge, the first author's goal was to help the student become more academically successful all around. Participant 2 was an eight-year-old male who was diagnosed with Attention Deficit Hyperactivity Disorder (ADHD) and a conduct disorder $(C D)$. He was placed in a behavior intervention classroom after destroying his kindergarten classroom. He was diagnosed as having a learning deficiency in reading, mathematics, and expressive language. When first author administered the Woodcock Johnson Test of Achievement III, (Woodcock, McGrew, \& Mather, 2001) he scored well below grade level as well as age level over all. After assessing the test it appeared the main problem area was reading, which affected all other subject areas. He was chosen for the study because phonic instruction had not been successful in teaching him reading. Sight word instruction was suggested and he enjoyed games (reading racetrack can appear as a game initially to students).

The study was conducted in a self-contained behavior intervention classroom. There were seven additional students to the two in the study in grades kindergarten through third. The school was located in a large suburban school district in the Pacific Northwest. At all times there were four adults in the classroom. This included the first author, a certified teacher, a behavior intervention technician, and an educational assistant. These other students had various disability designations including autism, ADHD, conduct disorder, bipolar, and fetal alcohol syndrome. Sessions were held Monday through Friday during the morning, anywhere between 10:00 a.m. and 11:00 a.m. The study was conducted at the back of the classroom in a quiet area of the room. 


\section{Materials}

A reading racetrack was used for each student. The racetracks were modeled off those found elsewhere (Alexander et al., 2008; McLaughlin et al., 2009; Rinaldi et al., 1997). Participant 1 had a reading racetrack that was laminated on an 11 " by 17 " yellow piece of paper. Participant 2 had a reading racetrack that was laminated on an 11 " by 17 " blue piece of paper. Both participants used flashcards that had been placed on three by five inch index cards. The flashcards were laminated and letters were made with a Circuit Expressions Machine and the cartridge Platinum Schoolbook. Sight words were placed on the flashcards and the letters were printed in blue on white index cards. The size of the letters was approximately 2.5 inches. The words were written on the laminated reading racetrack with whiteboard erasable marker in red. A stopwatch was used to time the students as they read around the racetrack. A data sheet was used for each student with the various words for the specific racetrack being used. A pencil was used to mark in correct and incorrect responses on the data sheet.

\section{Dependent Variables and Measurement Procedures}

The major dependent variables were student corrects and errors. A correct response was defined as the student saying the word within three seconds and if the student self corrected before moving on to the next word it was also scored as correct. An error was defined as the student saying the wrong word or saying skip. When reading on the racetrack, if the student did not finish reading in one minute, any word left on the track was marked as incorrect. Correct responses were recorded as plus signs while errors were recorded as minus signs. These data were collected on a specific data sheet for each participant and set of words. Each data sheet had the 28 words listed down the side. There were columns and rows that corresponded to a specific day and word. Each word appeared four times on the reading racetrack, so when recording everything except baseline and review tracks, four marks were made in the box for that word each day.

\section{Experimental Design and Conditions}

A multiple baseline design (Barlow, Nock, \& Hersen, 2008) across students was employed to assess and evaluate the effects of the intervention package. The intervention began with a baseline of two days with Participant 1 and baseline of three days with Participant 2 . After baseline was taken, intervention with the reading racetrack and flashcards began. Each session of intervention ran between 10 to 15 minutes. 
Pre-assessment. Before beginning baseline and intervention, a pretest was given. The pretest was made up of one, two and three letter words from the list of 240 most commonly used words. The words were presented with flashcards and the first author kept track of errors and corrects on a corresponding data sheet. If a participant did not know a word, he would say “skip." An error was marked as a (-), and a correct response was marked as a (+). From the information collected from the pretest, the words lists for future racetracks were created. Participant 1 knew all his letters and word lists were created out of two letter words. Participant 1 scored 52 out of one 138 correct. Participant 2 knew all his letters, some of his two letter words, and a few of his three letter words. He scored 80 out of 138. From this information, word lists were created. The word lists were created based on words that did not sound alike or look alike. Also, a word that was known for Participant 2 was placed in each of his word lists. The word lists were grouped by fours. Each list contained seven words. There was a racetrack for list one through four and the words appeared on the track four times (seven words appearing four times was 28 boxes on the track). The fifth racetrack was a review track with words from list one through four appearing once on the track.

Baseline. Baseline began after the pretest with the 28 words from word lists one through four for both Participant 1 and Participant 2. The participants were presented with flashcards with words on them. They were asked to say the words and were not given feedback regarding their answers. If the participants had not responded after three seconds, they were asked if they knew the word, to try to sound it out, and if not, the word was counted as an incorrect and skipped. Participant 1 had two days of baseline data, while Participant 2 had three days of baseline.

Reading racetracks $(R R)$ with DI flashcards and token reinforcement and response cost system. After baseline, Reading Racetracks with Direct Instruction flashcards with a token reward and cost system was presented to the participants. At the beginning of each session the participants practiced the seven flashcards for the day. Each flashcard was presented one by one and feedback was given. If the participant made an error or did not know the word, the first author would say the word, have the participant repeat the word, then the first author would repeat the word again. The flashcard that was missed would be placed back in the stack to repeat instruction. All the flashcards were practiced until the participant said the words without hesitation. Each participant was instructed with the flashcards separately. 
The racetrack procedure was then presented. The seven words that had been on the flashcards were placed randomly around the racetrack, each appearing four times. During the beginning session the participant said a flashcard and next found the word on the racetrack to help recognize the difference in the writing and color of the words. The flashcards were then put away and the participant was instructed that he would have one minute to read around the track before the first author would say stop. If the participant hesitated with a word, he could skip it, but he was encouraged to try. The timer was started when the first author said "go." The participant read around the track for one minute. The first author pointed to each word with a pencil as the participants read around the track. Participant 1 read counter clockwise while Participant 2 read clockwise around his track. Praise was given during the reading of the track and participants were encouraged to keep trying and sounding out words even if they hesitated or paused. Each participant was given a "practice timing" and if words were missed, they did the timing again. This gave the participants the opportunity to correct mistakes and learn from their errors. During the real timing the students were instructed that the first author would be keeping track of mistakes and correct responses. The first author had a corresponding data sheet in which the words were located. Since each word appeared four times, there were four marks that could be placed in the box on the data sheet each day for every word. Incorrect responses were skipping a word, saying a different word, or mispronouncing the word. Correct responses were saying the correct word or self-correcting before moving on to the next word. If a participant did not complete the racetrack in one minute, all words after the one-minute mark were counted as errors. At the end of each session, the first author would add up correct and incorrect responses. The participants both enjoyed knowing how quickly or slowly they read around the racetrack, so the time was written on the track with a dry erase marker. This was the time to beat for next session with an increase in correct responses.

A token economy with a response cost component (McLaughlin \& Williams, 1988) was also established as part of the RR and DI flashcard procedures. During each session, the participants could earn up to five tickets. Correct responses earned from one to two tickets, while remaining seated (feet on the floor, pockets on the chair and facing forward) earned a ticket. The participants could lose tickets (response cost) for swearing, hitting, throwing their work, or being out of seat. One ticket was lost, but an additional ticket was removed if the behavior continued. No more than five tickets would be removed before the participants had to stop and sit down. The remaining tickets were later exchanged for toys or candy available 
in the classroom store. The rewards included a wide range of toy cars, army men, tech-decks (mini-skateboards), bouncy balls, high-lighters, bubble gum, lifesaver candy, and peanut $\mathrm{m} \&$ m's. Each Friday the participants who had worked productively throughout the week could trade in their tickets for rewards.

\section{Reliability of Measurement and Fidelity of the Independent Variables}

Interobserver agreement was collected for each participant. The educational assistant, behavior interventionist, or the certified teacher would take the data when doing agreement for that day. After the end of the session when the student had read through the racetrack after a minute, the two observers talked about their data. They separately added up the number correct and number missed and discussed any questions. The interobserver agreement for Participant 2 was $100 \%$. This was found by dividing the smaller number by the larger number then multiplying by 100 . Interobserver agreement was taken $9 \%$ of the sessions for participant one. The interobserver agreement for participant 1 was $100 \%$. Interobserver agreement was taken $16 \%$ of the sessions for Participant 2.

Data regarding the fidelity of the implementation of the independent variables (Horner, Carr, Halle, McGee, Odom, \& Wolery, 2005) were gathered on six separate occasions. The second or third author would come to the classroom and observe the first author implementing the procedures with one or both of the participants. If all of the procedures were being implemented correctly then it was defined as appropriate implementation of the procedures. If any step or component was not seen, it was scored as not being implemented correctly. Fidelity data for each of the observations was always $100 \%$.

\section{Results}

\section{Participant 1}

The number of words read correctly and incorrectly during baseline and reading racetrack intervention can be seen in Figure 1. During baseline the participant scored an average of 6.5 correct with an average of 21.5 errors. Throughout the reading racetrack and DI flashcard intervention the average correct rate increased to 24.5 (range 17 to 28) and the error rate decreased to an average rate of 3.4 (range 0 to 12 errors). 


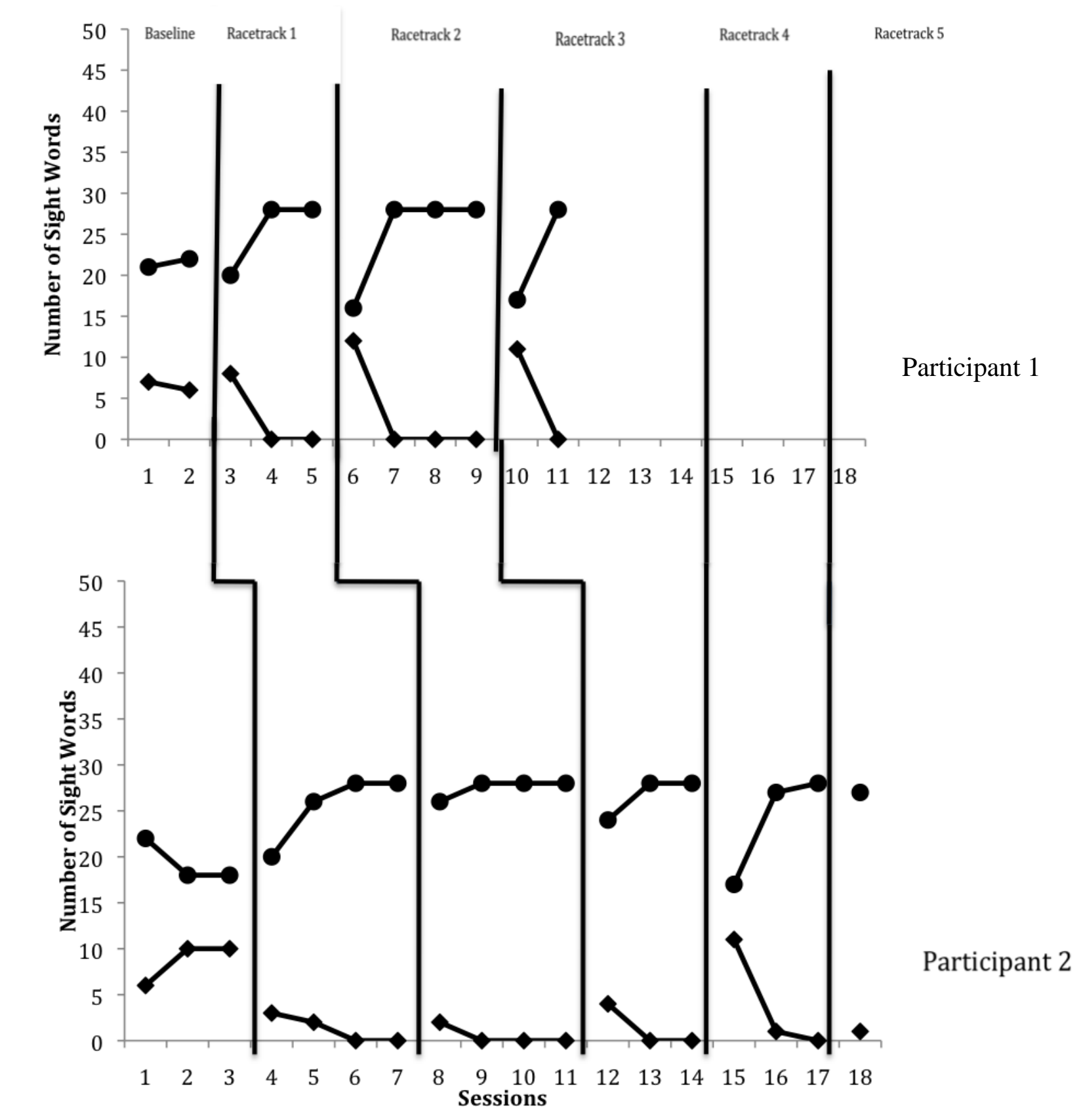

Figure 1. The number of corrects (closed circles) and errors (closed triangles) for baseline and for the intervention package for each racetrack word list for Participants 1 and 2.

Word list one, containing seven words, was presented with the flashcards and racetrack for three sessions. The first session the participant had 20 correct responses and 8 errors. The following two sessions with this word list the participant had 28 correct responses and no errors. Word list 2 was presented over four sessions. During the first session with the flashcards and racetrack, the participant had 16 correct responses and 12 errors. The follow- 
ing three sessions the student had 28 correct responses with no errors. Word list 3 was presented over two sessions. The first session the participant had 17 correct responses and 11 errors. The second session the participant had 28 correct responses and no errors. The participant had to end the intervention before finishing all the word lists because he began mainstreaming full time in a regular education first grade.

\section{Participant 2}

The number of words read correctly and incorrectly is shown in Figure 1 on the bottom panel. During baseline the participant scored an average of 8.7 correct responses and 19.3 errors. Throughout the racetrack, DI flashcard intervention and token economy, the correct responses increased to an average of 26 while his errors decreased to an average of 2 per session (range 17 to 28 correct responses with 0 to 11 errors).

Word list 1 was presented over four sessions. During the first session the participant had 8 errors with 20 correct responses. The second session decreased the errors and increased the correct rate. There were 2 errors and 26 correct responses. The following two sessions had 28 correct responses with no errors. Word list 2 began after the four sessions of word list one. Participant 2 only had 2 errors with 26 correct responses during the first session. In the following three sessions, he had 28 correct responses and no errors. Word list 3 was presented over only three sessions. In the first session the participant had 24 correct responses and 4 errors. The two sessions after each had 28 correct responses with no errors.

When the fourth word list was presented over three sessions, it generated more errors then the three previous word lists. It was presented Participant 2 had 17 correct responses with 11 errors during the first session. During the second session the participant improved (27 correct responses with 1 error). In the final session the participant had 28 correct responses and no errors.

The fifth word list contained all 28 words from word lists one through four. The fifth word list was presented over one session. The participant had 27 correct responses and 1 error. Due to the trends in baseline for Participant 2, a repeated analysis of variance (Siegel, 1956) was carried out with both the corrects and errors for each participant. There was a significant treatment effect $(F=783.084 ; d f=5 ; p=.0001)$. All follow-up comparisons using a 
Fisher PLSD Test were significant except for both corrects and errors between reading the various intervention phases and baseline for each participant.

\section{Discussion}

The results have shown that the intervention with reading racetrack and direct instruction flashcards was successful. Both participants increased their correct responses while decreasing errors. The participants increased their fluency and accuracy with the various sight words presented. Both participants gained confidence during the sessions, and they began to find reading a task that can be accomplished, rather than having a rise in behavior during reading. The participants' behavior did decrease during the presentation of the flashcards and racetrack. The token economy was a positive system to employ for them. Overall, this was a very successful intervention.

When the pre-assessment and baseline began, the participants both had difficulties staying in their seats, staying on task, and not getting angry during reading. The token economy was used to reward the students for on-task behavior. The students both excelled with the system. Participant 1 had a huge increase with staying in his seat. Participant 2 had an increase in confidence and not getting frustrated during reading. The classroom personnel felt that token economy was a successful part of the intervention.

Among the token economy, there were several other positive outcomes. Both participants began to read more outside the reading racetrack. The participants started to generalize while reading books, and if a word seemed hard they still make an effort to sound it out rather than have a behavior problem. Another positive outcome was the participants being willing to work with different adults. The first author was a new figure in the classroom. Both participants hesitated when working with the first author but at the end of the study were more willing to work with any new adult that entered the classroom. The final positive outcome was that the study replicated previous similar studies with a lot of success. Previous research has employed with reading racetracks and flashcards (Alexander et al., 2008; Becker, McLaughlin, Weber, \& Gower, 2009; Glover, McLaughlin, Derby, \& Gower, 2010; Green, et al., 2010; Kaufman et al., 2011; Rinaldi \& McLaughlin, 1996; Ruwe et al., 2011) as well as a token economy (McLaughlin \& Williams 1988). By replicating studies, this study increases 
the evidence of the confidence regarding the efficacy of reading racetracks, DI flashcards, and token economy (Barlow et al., 2008; Kazdin, 2010).

The strengths of the present research included its low cost, ease of implementation, the use of multiple participants, and the use of a rigorous single case experimental design to document effectiveness. The materials employed were easy to find and affordable. The toys and candy for the participants to buy with their tickets were purchased at a dollar store. The total cost for everything was approximately $\$ 30.00$. This was viewed as relatively inexpensive. This was especially true considering the gains that were noted for both of our participants. These procedures were able to be successfully implemented by available school personnel in across a wide range of classroom settings (resource room or self-contained classrooms), with various student groups (elementary and middle school students), and with a large variety of disability designations (learning disabilities, autism, conduct disorders, OHI, ADHD, and intellectual disabilities.

There were several limitations in the present research. These weakness include very few sessions of reliability data taken, data was taken for a short amount of time, data collection was terminated at the end of the first author's completion of student teaching requirements, there were only boys in the study, and the study had no follow up. Reliability data was limited because of the demanding nature of the classroom and limited assistance during the sessions. The data collection was taken for a short period of time because the first author completed her student teaching experience. After leaving the classroom the data collection ended. The classroom had eight boys and one girl. Having a limited amount of students to chose from limited the diversity of the study. Follow up data could not be taken was due to the nature of the first author's time in the classroom. Since the first author was in the classroom as a student teacher, follow up data collection was not possible. Finally, the threecomponent treatment package consisting of a token reward and cost system, reading racetracks, and DI flashcards was implemented. The separate effects of each of these could not be examined. However, both the classroom staff as well as the first author felt, that such a component analysis would be interest. However, this will have to occur in future research. One could counter-balance the order in which these phases would be implemented or withdrawn or employ an alternating treatments design. A final method would be to systematically withdraw components of the intervention package and return to the total intervention package (Barlow 
et al., 2008; Kazdin, 2010). See Wacker, Steege, Northup, Sasso, Berg, Reimers, et al. (1990) for an example examining the various components of functional communication training.

To determine further effectiveness of the study, it would need to be implemented across different participants and different settings. Although the participants will not be continuing with the reading racetracks, they will be continuing with reading instruction. Their instructional level has increased from the study and both have the confidence to be successful in their classrooms. Finally, the use of reliability for implementation of the various experimental manipulations adds strength to the present findings (Horner et al., 2005).

\section{References}

Adams, M. J. (1990). Learning to read: Thinking and learning about print. Cambridge, MA: MIT Press.

Alexander, C., McLaughlin, T. F., K. M. Derby, \& Cartmell, H. (2008). The effects of reading racetracks on sight words across four elementary students with differing disabilities. The Open Rehabilitation Journal, 1, 47-52.

Barlow, D. H., Nock, M., Hersen, M. (2008). Single case research designs: Strategies for studying behavior change ( $3^{\text {rd }}$ ed.). New York: Allyn and Bacon.

Barton-Arwood, S. M., Wehby, J. H., Falk, K. B. (2005) Reading instruction for elementaryage students with emotional and behavior disorders: academic and behavioral outcomes. Exceptional Children, 72, 7-27.

Becker, A., McLaughlin, T. F., Weber, K. P., \& Gower, J. (2009). The effects of copy, cover, and compare with and without error drill on multiplication fact fluency and accuracy. Electronic Journal of Research in Educational Psychology, 8, 747-760.

Brasch, T. L., Williams, R. L., \& McLaughlin, T. F. (2008). The effects of a direct instruction flashcard system on multiplication fact mastery by two high school students with ADHD and ODD. Child \& Family Behavior Therapy, 30(1), 51-59..

Carnine, D., \& Silbert, J., Kameenui, E. J., \& Tarver, S. G. (2010). Direct Instruction reading (5th ed.). Upper Saddle River, NJ: Merrill/Prentice-Hall/Pearson.

Cunningham, A. E., \& Stanovich, K. E. (1997). Early reading acquisition and its relation to reading experience and ability 10 years later. Developmental Psychology, 33, 934 945.

Falk, M., Band, M., \& McLaughlin, T. F. (2003). The effects of reading racetracks and flashcards on sight word vocabulary of three third grade students with a specific learning 
disability: A further replication and analysis. International Journal of Special Education, $18(2), 51-57$.

Gettinger, M. (1985). Effects of teacher-directed versus student-directed instruction and cues versus no cues for improving spelling performance. Journal of Applied Behavior Analysis, 18, 167-171.

Glover, P., McLaughlin, T. F., Derby, K. M., \& Gower, J. (2010). Using a direct instruction flashcard system employing a back three contingency for errors with two students with learning disabilities. Electronic Journal of Research in Educational Psychology, 8(2), 457-482.

Green, C., McLaughlin, T. F., Derby, K. M., \& Lee, K. (2010). The effects of reading racetracks and flashcards on the teaching of sight words to two sixth grade students with moderate disabilities. Journal of Educational Research, JER, 13(2), 84-98.

Grossen, B. (1995) The story behind project follow through. Effective School Practices, 15, 31-37.

Hayter, S., Scott, E., McLaughlin, T. F., \& Weber, K. P. (2007). The use of a modified direct instruction flashcard system with two high school students with developmental disabilities. Journal of Physical and Developmental Disabilities, 19, 409-415.

Heward, W. L. (2008). Exceptional children: An introduction to special education ( $9^{\text {th }}$ ed). Upper Saddle River, NJ: Merrill/Prentice Hall.

Horner, R., Carr, E., Halle, J., McGee, G., Odom, S., \& Wolery, M. (2005). The use of single-subject research to identify evidence-based practice in special education. Exceptional Children 71, 165-180.

Kaufman, L., McLaughlin, T. F., Derby, K. M., \& Waco, T. (2011). Employing reading racetracks and DI flashcards with and without cover, copy, and compare and rewards to teach of sight words to three students with learning disabilities in reading. Educational Research Quarterly, 34, 24-44.

Kazdin, A. E. (2010). Single case research designs: Methods for clinical and applied settings $\left(2^{\text {nd }}\right.$ ed.). New York: Oxford University Press.

Krashen, S. (2002). Defending whole language: The limits of phonic instruction and the efficiency of whole language instruction. Reading Improvement, 39, 32-42.

Liberman, I. Y., \& Liberman, A. M. (1990). Whole language vs. code emphasis: Underlying assumptions and their implications for reading instruction. Annals of Dyslexia, 40, 5176. 
Marchand-Martella, N. E., Slocum, T. A., \& Martella, R. C. (Eds.). (2004). An introduction to direct instruction. Boston, MA: Pearson Education, Inc.

McLaughlin, T. F., Weber, K. Derby, K. M., Hyde, C.,Violette, A., Barton, C. et al. (2009). The use of a racetracks procedures to improve the academic behaviors of students in special and remedial education: Suggestions for school personnel. In O. Demir \& C. Celik (Eds.). Multimedia in education and special education (pp. 55-81). Columbus, $\mathrm{OH}$ : Nova Publishers.

McLaughlin, T. F., \& Williams, R. L. (1988). The token economy in the classroom. In J. C. Witt S. N. Elliott, \& F. M. Gresham (Eds.). Handbook of behavior therapy in education (pp 469-487). New York: Plenum.

Morgan, D., \& Jenson, W. (1988). Teaching behaviorally disordered students: Preferred practices. Columbus, $\mathrm{OH}$ : Merrill.

National Reading Panel. (2000). Teaching children to read: An evidence-based assessment of the scientific research literature on reading and its implications for reading instruction (National Institute of Health Pub. No. 00-4769). Washington, DC: National Institute of Child Health and Human Development. Washington, DC: National Academy Press.

National Research Council. (1998). Preventing reading difficulties in young children. Washington, DC: National Academy Press.

Reyhner, J. (2008). The reading wars. Flagstaff, AZ: Northern Arizona University Press.

Rinaldi, L., \& McLaughlin, T. F. (1996). The effects of reading racetracks on the fluency of see-to-say words in isolation by a student with learning disabilities. Journal of Precision Teaching and Celeration, 13(2), 44-52.

Rinaldi, L., Sells, D., \& McLaughlin, T. F. (1997). The effects of reading racetracks on the sight word acquisition and fluency of elementary students. Journal of Behavioral Education, 7, 219-233.

Ruwe, K., McLaughlin, T. F., Derby, K. M., \& Johnson, K. (2011). The multiple effects of direct instruction flashcards on sight word acquisition, passage reading, and errors for three middle school students with intellectual disabilities. Journal of Developmental and Physical Disabilities. 23, 241-255.

Sante, D. A., McLaughlin T. F., \& Weber, K. P. (2001). The use and evaluation of a Direct Instruction flash card strategy on multiplication facts mastery with two students with ADHD. Journal of Precision Teaching and Celeration, 17(2), 68-75.

Siegel, S. (1956). Nonparametric statistics for the behavioral sciences. New York: McGraw-Hill. 
Silbert, J., Carnine, D. W., \& Stein, M. (1981). Direct instruction mathematics. Columbus, $\mathrm{OH}$ : Charles E. Merrill.

Trout, A. L., Epstein, M. H., Nelson, R., Synhorst, L., Hurley, K. D. (2006). Profiles of children served in early intervention program for behavior disorders. Topics in Early Childhood Special Education, 26, 206 - 218.

Wacker, D. P., Steege, M. W., Northup, J., Sasso, G., Berg, W., Reimers, T., Cooper, L., Cigrand, K., \& Donn, L. (1990). A component analysis of functional communication training across three topographies of severe behavior problems. Journal of Applied Behavior Analysis, 23, 417-429.

Woodcock, R. W., McGrew, K. S., \& Mather, N. (2001). Woodcock Johnson Psychoeducational Battery. Reading Meadows, IL: Riverside Publishing. 